\title{
CENTRAL ASIA AND THE GLOBALISATION OF THE \\ CONTEMPORARY LEGAL CONSCIOUSNESS
}

\author{
AKBAR RASULOV \\ University of Glasgow \\ School of Law \\ 5-9 Stair B uilding \\ The Square \\ Glasgow G $128 Q$ Q, UK
}

A BSTRACT. What is the logic which governs the processes of legal globalization? How does the transnational proliferation of legal forms operate in the contemporary geojuridical space? What are the main defining characteristics of the currently dominant mode of transnational legal consciousness and how can the concept of legal consciousness help us understand better the historical ebb and flow of the Western-led projects of good governance promotion in regions like Central A sia after the fall of the Soviet Union? Using Duncan K ennedy's seminal essay Three Globalizations of Law and Legal Thought as its starting platform, this essay seeks to explore these and a series of other related questions, while also drawing on the work of the Greek M arxist lawyerphilosopher Nicos Poulantzas to help elucidate some latent analytical stress-points in Kennedy's broader theoretical framework. Reacting against the neo-Orientalist tone adopted across much of the contemporary field of Central A sian studies, it develops an alternative account of the internal history of the legal-globalizational encounter between the W estern-based reform entrepreneurs and the national legal-political elites in Central 
A sia in the post-1991 period, complementing it with a detailed description of the general institutional and discursive structures within which this encounter took place.

KEY W ORDS. Central A sian law; critical comparative law; law as imperialism; legal consciousness; legal globalization; M arxist critique of transnational legal processes; postSoviet legal history;

I.

This essay is the product of an intellectual encounter that began about a decade ago. At the centre of this encounter lie two texts. The first of these texts is Duncan Kennedy's Three Globalizations of Law (Kennedy 2006a). In many ways, I suppose, it can be regarded as the main 'trigger event' behind this symposium and all the different debates that are reflected in it. The particular debate to which I imagine this essay to be a contribution, the debate about the globalisation of transnational modes of legal consciousness, would certainly not have taken place had it not been for Kennedy's ground-breaking article.

The second text in the shadow of which I develop my argument in these pages is Nicos Poulantzas's Internationalization of Capitalist Relations and the Nation-State (Poulantzas 2008). Though largely unfamiliar in contemporary legal circles, it represents to my mind what has to be regarded by any measure as one of the most important advancements in the critical study of global governance in the last fifty years. This essay should be considered a homage to that tradition of inquiry as much as it is to K ennedy's writings on legal globalisation, though it is mainly about the latter that I write here. ${ }^{1}$

\footnotetext{
${ }^{1}$ For an earlier rendition of the 'three globalizations of law' argument, see K ennedy 2003.
} 
A brief word about the broader context surrounding what is about to follow. The initial setting in which my reaction to Kennedy's work began to develop was shaped for the most part by a set of experiences, partly 'personal' but in large measure also 'academic', at the root of which lay what in Kennedy's vocabulary would be called the diffusion of the contemporary legal consciousness (hereafter, CLC) into the post-Soviet Central A sian legal space. ${ }^{2}$ B efore I was first introduced to K ennedy's writings, the main impression I had had of the way this subject was typically approached in the specialist comparativist and transitologist literatures in the W est was - not too atypically, I suppose - one of profound and ceaseless bewilderment mixed with occasional exasperation. Who were all these experts, scholars, and international civil servants who produced these 'reports', 'analyses', and 'background notes'? Where did they all get their ideas about Central A sia from? Had they even set foot ever anywhere in the region? However much allowance one were to make for the idea of the difference of perspectives, it seemed very difficult to take a charitable view of any of those accounts one saw regularly coming from the pen of W estern commentators writing about the post-Soviet experiences in the fields of political, legal and institutional reforms in Central Asia. For one thing, they almost without fail consistently misrepresented some of the most elementary features of the Central Asian political, institutional and legal landscape. For another, they also constantly tended to obscure a lot more than they managed to reveal. They failed to recognise what was central and fundamental and focused instead on what was trivial, superficial and mostly transient. They regularly missed patterns and trends that by any standard of appreciation had to be considered genuinely significant and yet at the same time were ready to erect whole webs of conjecture on the back of entirely inconsequential

\footnotetext{
${ }^{2}$ In modern usage, the term 'Central Asia' normally refers to the five former Soviet republics of K azakhstan, K yrgyzstan, Tajikistan, T urkmenistan, and U zbekistan.
} 
events and empty gestures. What is more, they did all this with such an air of intellectual certainty that one had really no idea if one ought to be simply worried or incensed.

Then again, what could one do about all these exercises in creative writing anyway? Given my inescapable embeddedness in that very reality which formed the object of those discourses, how was it possible for someone in my position to challenge the fictions they spawned without immediately opening oneself to the stereotypical charges of false loyalty and nativist bias? As soon as one stepped on that path anything one would say would be immediately challengeable as a projection of some misguided sense of patriotism or the failure to 'look at things objectively', and no matter how justified and legitimate it would be then to challenge those challenges as examples of standard Orientalist practices, dismissing them on such grounds could hardly do much to undermine the power of those fictions.

For, indeed, they were not just any old fictions but deeply systematised mythologies in the same sense in which one might say that every large-scale long-term discursive project relies, ultimately, for its success on the maintenance of a certain set of organizational mythologies that supply its foundational doxa and sustain its regime of illusio. ${ }^{3}$ To expose these mythologies, however publicly, as fictitious or false would not do anything to their ability to endure. $\mathrm{N}$ ot least because, as Althusser had pointed out, an ideological construct can never be 'dissipated' simply by the mere fact of it being outed as, say, a product of misrepresentation. The knowledge of its being such a product, however, he then went on to add immediately, can always help in the discovery of its underlying conditions of necessity (Althusser 1969, p. 230). And it is here that I began to

\footnotetext{
${ }^{3} \mathrm{M}$ y understanding of the concepts of doxa and illusion is based on the work of Pierre B ourdieu (B ourdieu 1990).
} 
see the beginnings of my response to the traditional narratives about the course of the post-Soviet legal and institutional reforms in Central A sia.

To put the matter slightly differently: rather than focusing on highlighting the essentially false and tendentious character of these narratives, the truly critical move would be to try to work out the broader logic which made the emergence of precisely this cluster of narratives the most probable ideological scenario in that particular context in which it occurred.

Kennedy's Three Globalizations of Law did not, admittedly, give me any direct answers to what this logic might be. But it gave me the necessary analytical apparatus that enabled me to start working towards it. A nd even though in the end this apparatus, too, would turn out somewhat insufficient - a fact the confirmation of which, however, would only become possible after the reintroduction of Kennedy's basic theoretical framework into that highly complex conceptual territory which Poulantzas mapped out in his essay - my sense of abiding gratitude to that essay remains as firm today as it was in those moments when I first glimpsed the tentative openings it showed me.

II.

There has arisen in recent years a very strongly pronounced - and not entirely unselfconscious - trend in the field of what could be broadly called Central A sian studies to present the general course of the history of post-independence political, institutional, and legal reforms in the region as, essentially, the history of a tragic failure. ${ }^{4}$

\footnotetext{
${ }^{4}$ For a representative sample of texts, both scholarly works and expert reports, that exhibit, in varying degrees, the general pattern described in this section, consider (in no particular order): Gleason 2003; B rill Olcott 2005; W ooden and Stefes 2009; Jones Luong 2002; International Crisis Group 2013; International Crisis Group 2009; Human Rights W atch 2008; Human Rights W atch 2004; Blackmon 2011; Cooley 2012;
} 
What is the exact nature of this failure? The details vary from one account to another, but the general contours seem quite stable. A s appears to be commonly assumed by most commentators, scholarly and otherwise, the entire trajectory of legal, political and institutional transformations during the post-Soviet period in Central Asia can be fundamentally understood as the one long but ultimately aborted journey along the archetypal Fukuyamian trajectory, from the world of administrative planning and statist bureaucratism to the world of free-market economics and liberal democracy. Having started at some point in the aftermath of the disintegration of the USSR, this journey, it is understood, continued more or less without any major hiccups through the mid-1990s, before coming to an abrupt end sometime around the turn of the century, this premature termination marking, symbolically, both a moment of tragedy and, from the perspective of those partners, a moment of failure.

The general framework structuring the process had a fairly familiar appearance. ${ }^{5}$ The primary goal was to effect a process of controlled transition conceptualised as the implementation of a carefully calibrated package of reforms aimed at the rebalancing of the relationship between the public and the private sectors, liberalisation of the economy, and comprehensive reorientation of the political system towards human rights, democracy, and the rule of law. Given the condensed timeframes within which the whole process was to be completed and the fact that the essential question of what should be included in the reforms package had apparently already been settled through historical experience and as a matter of empirical political science, the role of the main vehicle for the realisation of the process was assigned to the national governments, the medium of

Sievers 2003a; Sievers 2003b; Johnson 2007; Cummings 2005; M enon 1999; Bakker 2006; I shiyama 2002; A n-N aim 2000; Parakhonsky 2000; Dave 2007.

${ }^{5}$ Compare the account offered in Dezalay and Garth 2002. 
choice through which reforms were to be realised became legislative action, and the principal interface for the transmission of the substantive know-how at the core of the reforms package was to be the multitude of the various W estern-sponsored technical assistance programmes. Law became the main site for the effectuation of transition, and the principal yardstick by which the success of the process was to be measured for the most part was to be sought in the approximation of the newly adopted legislative acts to international standards and global best practices passed on to the respective national governments by the respective teams of international experts.

Or, at least that was the general plan. W hat precipitated its unravelling at the start of the new century remains to a certain extent still a matter of debate. M ost accounts, however, tend to converge around two principal sets of tropes both of which build on the classical theme of hostilely predisposed national elites. A t one end of the spectrum, thus, one finds a cluster of tropes centred on the idea of a neo-Soviet revanchism. The common narrative here tends to suggest that the post-independence journey from administrative socialism to liberal democracy in Central A sia was aborted for the most part because the old nomenklatura types who had not been properly cut off from the positions of power in 1991, after weathering the storm of the early years of independence, had staged a successful comeback in the late 1990s, and in doing so bringing an end to all meaningful aspects of the reforms project, repressing civil liberties and democracy, co-opting the younger generation of leaders, and reinstituting old-school Soviet authoritarian order. ${ }^{6}$

\footnotetext{
${ }^{6}$ For typical illustrations of this narrative pattern, see Cummings 2005 (the themes of comeback and cooptation of the young are particularly prominent) and J ones Luong 2002 (lamenting the 'enduring strength of the Soviet system' but noting - in line with the logic of the revanchism argument as opposed to, say, the 'simple' 'Soviet conservation' thesis - that 'old formulas [repeatedly] produced new institutions').
} 
At the other end of the spectrum one finds a set of accounts focused around the themes of cultural determinism and endemic governmental corruption. Where the neoSoviet revanchism argument, thus, in effect seeks to reproduce the standard Orientalist repertoire by re-inscribing the basic O rientalist tropes into the body of the Soviet 'other', this set of accounts aim to recycle the Orientalist repertoire in its original, 'purer' form. ${ }^{7}$ The general narrative here tends to proceed from the assumption that what had really sunk the post-independence reforms project in Central A sia had, ultimately, nothing to do with its Soviet legacy. Rather, the key factor needs to be sought in the toxic combination of a strong clan-tribalist mentality historically shared across all Central A sian societies, weak traditions of civic governance, a deeply entrenched culture of rent-seeking, and flawed political accountability mechanisms. Once the oppressive hand of M oscow had been withdrawn, suggest the proponents of this argument, these four factors in one way or another came together to produce a perfect storm of predatory statehood which triggered a nearly comprehensive hijacking of all government apparatuses by various forms of private interest and shady, mafia-style clannish networks. ${ }^{8}$

\footnotetext{
${ }^{7} \mathrm{M}$ y understanding of the concept of Orientalism is based on Edward Said's work (Said 1978).

${ }^{8}$ In a not unusual terminological turn, Ishiyama, for example, proposes to categorise all Central A sian states as 'neopatrimonial authoritarian states', with strongly pronounced rentier elements, organised around 'personalist regimes', in which 'personal loyalty and dependence permeate all political structures, and individuals occupy offices more for self-enrichment than to perform public services' (Ishiyama 2002, p. 43.) Unsurprisingly, it is this fact and none other which explains why any process of 'democratic transition' in the region should be expected to be 'particularly problematic [and] paniful' and will likely be unsuccessful. (Ibid., pp. 47-8.) Writing in the same volume, Cummings and Ochs propose a different taxonomic rubric: 'sultanistic regimes', including under it the notions of 'corruption', 'venality', 'personality cult', and (again) 'patrimonialism'. Interestingly, the account they offer of the Turkmen 'case' proceeds then to rely both on the more classical Orientalist repertoire of tropes and on the Soviet revanchism version. See, generally, Cummings and Ochs 2002.
} 
It is a matter of debate, of course, to what extent either of these narratives can in fact be shown to rest on a sufficiently reliable body of evidence. It seems to me that even the briefest glance at the general pattern of the post-independence dynamics in the region will confirm that neither of these accounts can contribute any meaningful insight into the basic course of events surrounding the evolution of the reforms project in Central A sia. But all this, in a way, is an entirely secondary point. W hat has to be emphasised rather as a matter of first order, to my mind, is the basic internal structure shared by both of these narratives.

Note, firstly, the rather obvious predilection repeated across both of these accounts towards representing the history of the post-independence transformations in Central Asia as one of a fundamental conflict between the forces of modernism and progress and the forces of conservatism and reaction. Note also that when it comes to explaining how one can determine at any given moment what might be the current 'state of play' in this conflict, the answer is found at all times in the field that is almost entirely made up of those processes which, if completed, would have resulted, logically, in the systematic reproduction across the whole Central A sian legal and institutional space of what, in effect, are W estern-style legal, political and institutional structures. If one were to read this structural sequence from a slightly different angle, one could conclude that what it effectively tries to imply to its audiences is that the essential course of the grand titanic battle between the forces of progress and the forces of reaction in contemporary Central A sia has to be measured in terms of its internal institutional Westernization, i.e. how well a certain set of W estern institutional arrangements has become diffused through the Central Asian social, legal and political space-processes. The growing resistance shown since the late 1990s by the Central A sian governments towards the idea that they ought to endorse and support this diffusion project then would not only explain, on this 
view of things, a large part of how and why these two narratives have become so intuitively appealing to the Western eyes, but also why the overarching emplotment pattern here has been built around the themes of tragedy (because the forces of progress lost) and failure (because progress was fought for and not achieved). ${ }^{9}$

Now, there is a lot, of course, that can be seen as problematic about this set of discursive strategies. For one thing, both the neo-Soviet revanchism narrative and the cultural determinism/endemic corruption narrative openly scream for a ruthless critical umasking as the ideological instruments of the worst kind of old school comparativist Orientalism. ${ }^{10}$ But what I would like to suggest here concerns a different matter.

The whole 'aborted journey' tradition of thought is a complete fiction. It fundamentally misrepresents the course of the post-independence history in the region. By projecting a vision built around the idea of a radical historical rupture, it glosses over a whole swath of events, trends and patterns of change that spread across the region's legal, political and institutional space, having started long before the purported ruptural point and continuing well after it, often accelerating in speed, ${ }^{11}$ the driving impetus for which, furthermore, by all accounts had had its origin in the very same processes through which the post-independence encounter between the Central A sian states and the West was first enacted. A lot of these trends and patterns have been inspired and provoked by

\footnotetext{
${ }^{9} \mathrm{M} y$ understanding of the theory of emplotment and the encoding of historical narratives more generally derives for the most part from W hite 1978, pp. 81-100, but also B ooker 2004.

${ }^{10}$ For a concise analysis of the various ruses and guises of Orientalism in comparativist literature, see Berman 1997.

${ }^{11}$ The idea of the lowering of the speed of transformation, indeed, is one of the major themes at the core of the 'aborted journey' tradition. See, e.g., Smith 2013 ('Change seems to come slowly to Central A sia. ... I think we' ve gotten used to [this idea]. The conversations I have with others of you who watch the region are peppered with how little [change we can] expect.')
} 
the various activities of Western states, international organisations and transnational policy entrepreneurs. $M$ any of them have led to rapid and far-reaching effects that cannot be immediately reconciled with any concept of a neo-Soviet revanchism or personalist clan-tribalist networks. One only needs to consider the evolution of changes in the fields of monetary policy, corporate law, the constitutional separation of powers, or the law of commercial transactions, not to mention trade liberalisation and privatisation reforms. The imagery of aborted journeys and abrupt terminations makes it impossible to recognise these changes as anything other than essentially random events of fairly marginal significance. And yet even the most cursory examination of their design, content and reception would leave no room for doubt that they not only left the deepest impact on the structural configuration of the region's legal-political space but that they also, fundamentally, all have their origin in that complex, continuously evolving encounter between the post-Soviet world and the 'international community' that had started in the early 1990s and that, in some form or other, has continued to this day.

The 'aborted journey' tradition is a myth and its political bias is fundamentally reactionary. And yet the story it tries to convey is certainly not without critical value. It tells us something very important about the internal logic of this tradition. A closer reading of the two narrative patterns through which it expresses itself suggests that the real story which its proponents are trying to write is not, in fact, about the history of the post-independence reforms per se, as it is about the history of the basic relationship between Central Asian governments and Western-origined policy reform entrepreneurs acting, for the most part, under the heading of multilateral aid programmes aimed at the provision of technical assistance and good governance expertise. It is a story that, for the most part, unfolds across a sequence of three stages. 
The first stage - what one may call the A ge of Enthusiasm - by most accounts began immediately after the disintegration of the USSR and extended, roughly, through the first half of the 1990s. The special case of Tajikistan aside, this was the time when the basic relationship between the W estern reform entrepreneurs and the national government officials was marked by the spirit of unbridled hopefulness, mutual trust, and can-do optimism. The national elites were keen to learn and adopt the 'global ways'; their W estern counterparts were eager to teach and share. The main vehicle through which the transmission of this global 'know-how' was meant to proceed was legislative reform, and the main hero figure at the heart of the whole process was cast normally in the form of an internationally-experienced foreign legal expert, preferably male, white and A nglophone. The expertise he would bring was meant to enable the newly independent Central A sian states to adopt in record short time the most innovative (de)regulatory and institutional techniques and launch their societies on the shiny road to freedom, justice and prosperity. The future seemed bright and the wind unmistakably blew in the 'international' direction.

The A ge of Enthusiasm did not last very long, though, unlike the first stage, the second stage did not on the whole have an easily identifiable starting point. In Turkmenistan it probably started earlier (by most accounts, sometime around 1995); in Kyrgyzstan, later (by most accounts, sometime after 1998). In Tajikistan, on the other hand, it is not clear if it took place at all, since the respective time stretch was taken over to some extent by the civil war of 1992-97. The two defining characteristics of the second stage were (i) a rapid increase in the general level of scepticism on the part of the national governing elites, especially in what concerned the substantive wisdom of the various new pieces of legislation, the adoption of which was urged by the international expert community; and (ii) a steadily growing exasperation on the part of the respective international institutions and their W estern donors, triggered by the sense that the process 
of reforms appeared to be stalling. Though this gradual dissolution of local trust may have been bad enough in itself, what made the situation even more exasperating from the point of view of the 'international camp' was the fact that, as far as the local side saw it, the process was not at all politically motivated. From the local point of view, the decisive momentum came from the ranks of the local technocratic communities, which, after the initial honeymoon period between them and their Western colleagues drew to an end, increasingly came to believe that the ever-widening stream of reform-related advice their states were getting from the international expert community was far more often than not a vehicle not just for 'bad economics' but also 'bad statecraft' and grounded in an atrociously poor understanding of the local institutional landscape and informal governance sectors. ${ }^{12}$ The more the relevance of international expertise came to be questioned by the local technocratic communities, the more urgent the tone of the international institutions and their Western supporters started to become, the more entrenched, as a consequence, became the impression shared across the local political establishment that the entire reforms project may very well not be what it was initially presented to be. The increasingly obvious pattern of systematic mismanagement ${ }^{13}$ and

\footnotetext{
${ }^{12}$ In a telling anecdote from his early days as a W estern reform entrepreneur, Sievers describes how, when administering grants under human rights programmes, W estern donors and international institutions in the region would routinely 'thr[o]w out applications of any applicants over 40 on the explicit assumption that they were "too set in their ways" [and] prefer a 20-year old student with no discernible commitment to a 45-year old dissident who had continued human rights work in the Soviet era despite repression.' (Sievers 2003a, p. 210).

13 ، [In administering all Global Environment Facility projects,] UNDP takes [a] \$146,000 [cut]. A ssuming that most such projects are roughly $\$ 750,000$ (and cannot be more than one million), UNDP's fee is slightly under $20 \%$. For projects under $\$ 750,000$, UN DP's take would still be $\$ 146,000$. . $^{\prime}$ (Ibid., 234)
} 
easily observable nepotism among the international expert community certainly did nothing to dispel that impression (Sievers 2003a, pp. 163-70).

The third stage, which started sometime around the turn of the century and which has by and large continued to this day, came, therefore, to be experienced from the point of view of the international camp as the A ge of Resentment. At times openly hostile, more often deeply suspicious, the overall tone of the day-to-day exchanges between the Western agents of the reform project and the local political establishment increasingly became a far cry from what it had been a decade earlier. Ranging from thinly disguised mutual antipathy in areas like human rights to knee-jerk distrust in the field of natural resources law, to perfectly reciprocal bitterness in the area of foreign investment - the regnant mood of the reforms encounter as perceived through W estern eyes seems very much that of a failed relationship ${ }^{14}$ and, for the international legal expert, spectacular fall from grace. ${ }^{15}$

\section{$* * * *$}

Now, I do not want to suggest that what follows below is a full-fledged alternative account. I do, however, wish to propose that a particular reading of Kennedy's work on

\footnotetext{
${ }^{14}$ See Cummings and Ochs 2002, p. 128: 'The [experience of] Central Asian regimes ... demonstrate[s] how the higher density of international exchanges, the emergence of a transnational civil society, and the end of the Cold War, are still insufficient to counter the emergence of nondemocratic regimes.' Cf. Smith 2013 (most policy engagements by the West with Central A sian regimes are now 'futile' since the local elites consider the 'lack of political progress desirable').

${ }^{15}$ Thus, as early as 2003, the question 'who lost Central A sia?' became one of the main tropes around which the transitologist discourses of the Age of Resentment began realigning. See, eg, Sievers 2003b; Blackmon 2011, pp. 1-3. Cf. Foust 2012 (it was the 'W estern elites' that failed 'to come to grips with Central Asia on its own terms', the outcome of which was Central Asian governments' turning to 'bad policy and missing choices').
} 
the theory of legal globalisation (and Poulantzas's essay too) can enable us to develop an interpretative angle that will explain the process behind this transition from the Age of Enthusiasm to the Age of Resentment far better than any of the narratives surveyed above. To see how this angle can be uncovered, we must take a few steps back.

III.

At the root of Kennedy's theory of legal globalisation lies the concept of legal consciousness. It needs to be noted right from the outset that, contrary to the obvious terminological parallels, it does not carry within it the same ideational content it would normally be saddled with in the orthodox Marxist discourse (Lukacs 1971, pp. 83-100), or, say, the Russo-Soviet tradition of socio-legal jurisprudence (Alekseev 1973). One should not, thus, view it as the projection of the quasi-Lukacsian formula of reification, nor as the name for that totality of attitudes and assumptions which are adopted within the broader social space with regard to the various elements of the positive legal order, such as, for example, the relationship between the judiciary and the executive or the law on arbitrary detention (Mal'ko 1996, p. 68). Nor, at the same time, should it be understood also as the designation of the most widespread legal-theoretic beliefs adopted within the community of legal academics, if by legal theory one should understand here the kind of knowledge one would typically acquire in a specialised jurisprudence course.

The basic content inhabiting Kennedy's concept of legal consciousness, as it has developed over the last forty years (Kennedy 2006b, pp. xiv-xvii, 5-7), refers to an entirely different social phenomenon. The fundamental distinction from which it arises, in a sense, is the distinction between what one may call mass consciousness, legal philosophy, and the collective imaginary of the legal profession lato sensu. It is only with the last of these three phenomena that Kennedy's theory of legal globalisation is formally 
concerned. ${ }^{16}$ Having said that, like a number of other scholars who have introduced this concept into their theoretical vocabulary (see, e.g., Horwitz 1992, pp. 9-31), Kennedy also, somewhat confusingly, tends sometimes to describe 'legal consciousness' as 'legal thought' (and at times also as 'mode of legal thought') (Kennedy 2006a, pp. 22-3). Regardless of such terminological shifts, the conceptual construct at all points continues to exhibit the same two defining features.

In the first place, especially when used as a synonym for the idea of legal tradition (see Kennedy 2008, pp. 196-204), it gives expression to what in a different context Kennedy himself calls an organicist theoretical sensibility (see K ennedy 2001, pp. 114958). The essential idea there seems to be that every mode of legal consciousness should be regarded, above all, as an integral part of some greater organic whole - that is to say, the only way in which one can begin to grasp its immediate specificity and internal logic is by understanding first the basic terms of its relationship with this greater whole by which it is constantly shaped and anchored (K ennedy 2001, p. 1149). W hat precisely may be the nature of this greater whole Kennedy never fully commits himself to explaining; at different points, thus, one finds indications suggesting it may be something like 'national culture', 'neoliberalism', 'capitalism', or even 'cultural imperialism'. ${ }^{17}$

In the second place, and very characteristically, Kennedy's concept of legal consciousness also tends to project a strongly semioticist theoretical vision (for Kennedy's view of semioticism, see Kennedy 2001, pp. 1175-83). The fundamental

\footnotetext{
${ }^{16} \mathrm{~A}$ different way to explain the idea of legal consciousness would be to describe it in terms of the juristic outlook of the legal profession. Unlike those aspects of the world outlook held by the members of the legal profession which relate to non-juridical matters, the concept of legal consciousness, on this view, would cover only those dimensions of this outlook in which assumptions 'about law' play the defining role.

${ }^{17}$ Compare, e.g., accounts offered in Kennedy 2006a, pp. 63-71, Kennedy 2006b, pp. xiv-xxxviii, and Kennedy 2008, pp. 196-204.
} 
assumption in this case seems to be that every mode of legal consciousness constitutes, at its root, a 'secondary modelling system' (U spensky and Lotman 1978), i.e. a languagelike apparatus which enables its users to process and organise a certain aspect of their lived human experience through sign-like structures. The main key to the comprehension of any given mode of legal consciousness, from this point of view, would be then to grasp the internal logic of this apparatus, which Kennedy perceives in the form of a loosely interconnected system of higher-order concepts, analytical presumptions, and typical reasoning templates in terms of which its practitioners typically articulate, represent, and organise their legal experiences, and which can thus be considered, metaphorically, as a 'local' case of the Saussurean langue. The governing assumption, thus, here is to present each mode of legal consciousness

as a vocabulary of concepts and typical arguments, as a langue, or language, and ... the specific, positively enacted rules ... as parole, or speech. ... J ust as there are an infinity of grammatically correct sentences that can be uttered in English, there are an infinity of regulatory statutes that can be formulated in the conceptual vocabulary of [a given mode of legal consciousness] and defended through an infinite variety of specific justificatory arguments formulated by combining and recombining the policy 'sound bites' of [that mode of legal consciousness]. (K ennedy 2006a, p. 23)

The invocation of 'regulatory statutes' should not mislead: what Kennedy has in mind by parole is not just acts of legislation but all patterns of 'positive' legal practices, including arguments about legislation and legal interpretation that are made in the course of regular legal process:

This is a very specific adaptation of the Saussurean distinction. The valid norm, or the proposed valid norm, is like a sentence - a unit of legal speech. Thus a jurisdiction's rule that the contract by correspondence is valid on the acceptance is a normative utterance; in the same legal langue, the jurisdiction might have 'said' instead that it was valid only on receipt. Or the rule might be that where the offeror revokes after mailing of the acceptance, but before receipt, he is liable only for the reasonable reliance of the offeree (and not for the expectancy). (Kennedy 2008, p. 200) 
The duality of the animating theoretical dynamics, organicism vs. semioticism, results in a somewhat unstable methodological concoction but, as a micro-level analytic, it seems essential to the practical functionality of Kennedy's concept, especially in what concerns the case of what Kennedy calls the CLC. Though it would have been possible, in principle, under the 'pure' organicist logic to propose any number of potential configurations of the CLC, the introduction of the semioticist element not only severely constrains this play of interpretative possibilities but also rigidly pre-determines the 'level' at which the existence of the CLC can be exclusively established. For, indeed, once we accept the general hypothesis that the operation of all forms of legal discourse in the given jurisdiction is governed by some kind of internal langue, a close systematic examination of the practices of legal discourse across any given geo-juridical space on a sufficiently large scale today will inevitably confirm that at the heart of all contemporary legal-discursive formations lies one single global langue.

By any measure, this is a bold claim, and it is here that $K$ ennedy's theory raises its two main challenges to the standard model of the legal-comparativist exercise and, with that, to the traditional understanding of the essential dynamics of 'what happened' in the course of Central Asia's encounter with the international community of reform entrepreneurs.

The first challenge should not be difficult to deduce. Because of its essentially globalised character, the CLC, suggests Kennedy, has more or less flattened out all traditional differences that used to separate discrete national legal systems at the level of their operative organisational processes. As Kennedy puts it, 'national traditions [now] don't exist except as accumulated speech' (Kennedy 2008, p. 200). Thus, it is only inasmuch as it has not yet become subsumed within the conceptual space of the CLC that any given national legal system can be expected to exhibit a genuinely distinct pattern of 
discursive operation and practical organisation. Once this process of subsumption has completed, however:

the national legal elites [begin to] operate with a common conceptual vocabulary ... and a common repertoire of potential rule solutions for new problems and arguments pro and con. They come up with different specific rules to govern specific cases, but we should understand these [differences only] as [occurring at the level of] parole. (K ennedy 2008, p. 200)

Note that this formulation, once it is accepted, not only makes it highly problematic to continue viewing the enterprise of comparative studies as the investigation of differences and commonalities across different jurisdictional contexts between discrete sets of rules, doctrines or institutions. ${ }^{18}$ It also highlights that the really important focal point for investigation here lies not so much in the field of the standard comparativist exercise, but in the domain which looks very much like traditional histoire des mentalités: at what point and under what conditions does the mentalité that is the CLC reach and engulf the given segment of the geo-juridical space?

The second challenge is not so obvious. Even though it has an essentially global ised character the langue structure at the heart of the CLC, as K ennedy envisions it, is not an inherently global construct. Rather, every one of its main defining patterns has an easily traceable national origin. Thus, even though the practical reach of the CLC today may be truly universal, at its historical root one inevitably finds the same national signature: 'each of the traits of [the CLC] has a recognizable U nitedstatesean genealogy' (K ennedy 2006a, p. 67). On this view of things, then, it is not so much the case anymore that the main question at the centre of the inquiry should be 'how do legal forms travel from one setting to another?' but, rather, 'what is the mechanism by which this diffusion

\footnotetext{
${ }^{18}$ Cf. K ennedy 2011, p. 189: 'In this genre, we study not "transplants" of particular legal rules or even of a whole body of law, but the dissemination of the discursive practices of actors who are producing law ... or, in the phrase of the Sacco school, the "circulation of models".'
} 
from the national to the universal has been achieved?' Kennedy's own answer to this question can only be fully understood when one looks at what he considers to be the main distinguishing traits of the CLC mode.

IV.

There seem to be two main trends which characterise the CLC langue (Kennedy 2006a, p. 22). One is the systematic move to balancing and proportionality techniques in all areas of legal reasoning. ${ }^{19}$ The other is the 'seemingly contrary' rise of a neo-formalist sensibility, especially in the areas of constitutional, criminal and international legal reasoning. What makes this combination particularly curious, observes $\mathrm{K}$ ennedy, is its obvious self-denial: the neo-formalist mind constantly "rebels in the name of "absolutes" [in each] particular context' and yet, when its workings are perceived across the broader field, it repeatedly turns out to favour the use of all kinds of advanced balancing techniques (K ennedy 2006a, pp. 65-7).

This combination may seem at first quite a riddle, but at a deeper structural level, argues Kennedy, it makes perfect sense. The reason for that lies in the fact that, firstly, the CLC constitutes 'the endpoint of a long process in which the general concept of a right has risen ... to become the universal legal linguistic unit', the most significant expression of which has been the ascendance of the human rights discourse. In a way, notes Kennedy, '[h]uman rights play the same role in [CLC] that "private rights" played in $\left[19^{\text {th }}\right.$-century legal thought]': they 'operat[e] as universals, at once natural and positive'; they 'function sometimes as rules (even absolute rules) and sometimes as mere

\footnotetext{
${ }^{19}$ The spread of the balancing/proportionalist sensibility represents one of the most important and yet entirely under-theorised episodes in the history of 'juridical technologies' over the last one hundred years. For K ennedy's understanding of this episode, see more generally K ennedy 2011.
} 
policies'; they provide, finally, the conceptual blueprint in terms of which all other legal conceptual constructs are reformulated and reorganised (K ennedy 2006a, pp. 65-6).

The tricky part here, however, is that, unlike in $19^{\text {th }}$-century legal thought, in the CLC the rights discourse has become comprehensively fused with identitarian discourse: the CLC 'organizes [all categories of] rights-claimants according to their ... cross-cutting "identities"'. A fundamental feature of the way in which the modern identitarian discourse operates, however, is its deep-seated commitment to essentialisation: in determining the conditions for the ascription of rights, the identitarian paradigm works by and large by 'essentializing what it is to have some particular trait that sets its possessors apart, in order to develop and legitimate legal claims'. It is an indispensable corollary of essentialistic thinking that any legal reasoning pattern erected on its basis will necessarily have a strongly pronounced formalistic bent. And yet precisely because the ontological foundations of this formalism derive from the field of 'social identities' and identity (a) always operates on multiple levels and (b) is a concept that articulates most readily the notion of 'a claim against the "majority" or "dominant culture", it is also an inevitable feature of this formalistic reasoning complex that it will constantly feel the pressure to organise the legal process as a process of pluralist mediation aimed at the reconciling of conflicting claims across different contexts, rather than their rigid enforcement in a Procrustean fashion (Kennedy 2006a, p. 66). A theoretical framework thus configured, unsurprisingly enough, will then have no choice but to develop a deeply contradictory attitudinal combination: at the conscious surface a culture of neoformalism, beneath it an unreflective commitment to pragmatic balancing.

The identity/rights complex, continues K ennedy, may seem at first to be only 'a public law and family law phenomenon. But it is in fact a true lingua franca, just as applicable in the law of the market.' The conceptual structure built around an identitarian 
sensibility ('even "the poor" [is now] an identity rather than a class') and the classical human-rights-inspired set of assumptions about how 'identities enter law' has penetrated every nook and cranny of the CLC landscape. Doctrines, regimes, and contestational settings that used to be articulated in terms of public policy or 'normal business practices' are systematically reorganised, under the $C L C$, on the basis of the identity/rights complex: from property and contract to competition and commercial law every aspect of legal practice is systematically remodelled on the basis of an analytical pattern that has been historically expressive of the non-discrimination debate in the human rights discourse (K ennedy 2006a, p. 66). Even the international business community, observes Kennedy, in an especially emblematic move 'adapted to the rise of identity rights rhetoric by transforming property ownership into a minoritarian identity and government regulation into the analogue of discrimination by legislative majorities' (Kennedy 2006a, p. 67).

The historical origins of this outlook that is at once formalist (and thus eminently given to privileging judicialised forms of legal reasoning) and identitarian (and thus eminently given to 'seeing' everything in terms of minority/majority relations and oppression/participation patterns) should not be a mystery:

The identity/rights complex, as a template for thinking about a vast range of legal issues, seems foreshadowed in the United States by the post-WWII alliance of elite WASPs, Jews, and blacks in the construction of the category of ethnicity, linking the evils of the Holocaust to those of racism in the U nited States as illegal discrimination. US second-wave feminism is responsible for the abstraction and generalization of the category by transforming it into 'identity'. A nd it is familiar since de Tocqueville that U nitedstatseans tend towards juristocracy. (K ennedy 2006a, p. 68)

Having been 'born' out of the US legal tradition, the identity/rights complex, contends Kennedy, was then progressively disseminated across the globe through the combination of three main mechanisms: (i) the initiation of a global judicial conversation enabled by 
the rise of what in other parts of the literature has been called 'spontaneous transgovernmental networks' (Slaughter 2003) that triggered the diffusion of a certain institutional outlook within the judicial profession, especially in areas such as constitutional law; (ii) 'the rise of transnational jurisdictions, in a host of different contexts, from the European Union to the WTO'; and (iii) 'the development of the USstyle large international law firm dealing with the issues of the globalized economy, and of a nonprofit NGO sector, equally globalized, understanding itself as constituting "the international community" or "international civil society"' (Kennedy 2006a, p. 68).

In each of these contexts, K ennedy observes, 'the influence of the U nited States is manifest', the levers used in the service of this influence ranging from 'more or less violent' projections of hard power (Italy, Germany, and Japan after World War II) to 'refusal of trade' and economic pressure (USAID programmes, US influence over structural adjustment lending in the Third W orld), to soft power derived 'from prestige', to the rise of US transnational corporations, which brought with it the rise of the respective segment of the US law firm market (K ennedy 2006a, pp. 68-9).

And yet, in the end, it would be wrong to see the story of the CLC's diffusion solely in terms of its U nitedstatesean origins. One should take care, warns K ennedy, not to misrepresent this process as 'just' another species of 'A mericanization': 'public law neo-formalism and [pragmatic balancing] have a European as well as a Unitedstatesean genealogy'. 'K elsenian judicial review and German ordo-liberalism' and the work of the European Court of J ustice have been as influential in shaping the CLC sensibility as anything else. Besides, one should not forget also that in addition to everything else there also exists 'a process of selection in which legal elites around the world [simply] choose to be dominated in one way rather than another'. It would be wrong to try to ground this 
process of selection at all costs in some idea of a Unitedstatesean quasi-imperial projection (Kennedy 2006a, p. 69).

$$
\text { V. }
$$

The story of the post-independence reforms project in Central A sia, as should probably have become apparent by now, is essentially an episode in the broader story of the global diffusion of the CLC. At its centre stands the process of the gradual arrival into the Central A sian discursive space of the CLC langue, its gradual internalisation by the local technocratic and political elites and, eventually, their re-appropriation of its rhetorical apparatus against the political agendas advanced by the international community of reform entrepreneurs. The moment of the abrupt termination so intensely mythologised by the 'aborted journey' tradition represents, thus, not so much an instance of a tragic failure for the grand modernisation project brought to the region by the reform entrepreneurs as an expression of its fundamental success, for the manner in which, first, the mounting scepticism of the local establishment came to be articulated and, second, the rhetoric of rejection with which the national governments subsequently came to greet those parts of the reforms package which they did not welcome on political grounds was essentially that of the neoformalist identity/rights model-inspired discourse.

Looking from this angle, it seems impossible not to notice how closely the general framework that structured this whole process resonates with various parts of Kennedy's account. $^{20}$

\footnotetext{
${ }^{20} \mathrm{I}$ base this part of my argument on my own personal experience in the region as well as the various reflected impressions I got over nearly two decades of continuous interactions with colleagues, peers, government officials, and international policy reform experts. Inasmuch as this inevitably gives my account a certain subjective bias, I have no choice but to acknowledge that.
} 
1. Principal agents of the reforms project

The main impetus for the reforms project traditionally has come from the United States, occasionally flanked by its EU partners (Britain, Germany, Finland, etc.), and the 'international civil society' manifested through a network of predominantly Westernbased transnational NGOs (Human Rights Watch, A mnesty International, etc.). The former have acted primarily through a network of bilateral aid and technical assistances projects operated by the USAID and the EU TACIS programme, the Bretton-Woods Institutions (BWI), and, to a lesser extent, UN-linked bodies (UNDP, UNHCHR, etc.) and the Organisation for Security and Co-operation in Europe (OSCE). The latter has acted mainly through W estern expatriate communities buttressed by a thin layer of local counterparts financed through charitable donations and grant schemes operated by W estern governments and, occasionally, a private donor community (Soros foundation).

\section{Secondary agents of the reforms project}

A further impulse that has reinforced the diffusion of the CLC langue came from the arrival into the Central Asian business scene of a range of powerful Western multinationals (Shell, Chevron, General Motors, etc.), closely followed by the leading transnational law firms (Baker \& McKenzie, White $\&$ Case, Mayer Brown, etc.). A consistent pattern among the former has been that they predominantly seem to represent the traditional power bases of the transnational industrial capital (but rarely transnational finance capital) and that they often seek to establish contact with local government elites directly (rather than rely on their embassies). ${ }^{21}$

\footnotetext{
${ }^{21}$ Given the stakes involved, it seems it would also be of value to note who was not on the list of the dramatis personae or who, relatively speaking, significantly under-contributed to the application of the
} 
3. Principal tools and avenues used for the advancement of the reforms project

Overall, there have been seven discrete sets of tools and institutional avenues that were used to advance the reforms projects:

- US embassy and the USAID;

- EU TACIS projects;

- conditional loans and credit facilities from the BWI;

- bilateral investment treaties with W estern states;

- international regime monitoring and reporting schemes (mainly, the UN human rights system and the OSCE);

- public and private aid initiatives coordinated by UNDP- and BWI-related structures;

- international human rights $\mathrm{NGO}$;

- bilateral and multilateral inter-governmental exchange and partnership programme.

A $n$ important element of the equation at all times has also remained the promotion and popularisation of Western-style legal education. This was achieved in practice in some cases through the creation of foreign campuses and regional branches for select Western universities (the American University of Central Asia in Bishkek, the Westminster University in Tashkent, etc.), the institution of generous postgraduate grants and scholarship schemes (International Research and Exchanges Board (IREX), Soros, and M uskie programs to support studies in the US; Deutscher A kademischer A ustausch

diffusionary pressure: China; non-European regional organizations (with the possible exception, in later years, of the Asian Bank of Development); emigrant communities and national diasporas. Again, the general signature seems to fit K ennedy's prediction. 
Dienst (DAAD) scholarships for Germany; Soros and British Council scholarships for B ritain; J apanese International Cooperation A gency (JICA) scholarships for Japan, etc.), and the organisation of international mooting competitions (the Jessup competition coordinated regionally by the A merican Bar Association ( $A B A$ ), the $M$ artens/Pictet competition coordinated by the International Committee of the R ed Cross (ICRC)).

\section{Principal strategies for the execution of the reforms project}

At every stage of the legal-globalisational encounter in Central A sia in the last two decades, an overwhelming majority of all efforts related to the promotion of reforms focused on the rewriting of the local statutory materials (legislative acts of parliament), the training of civil society leaders (with a strong focus on human rights and classical microeconomics), and reorganisation of the judiciary. ${ }^{22}$ A nother typical strategy pursued by the pro-reforms camp has been to urge the national governments to ratify en masse as many international treaties as possible. The underlying assumptional framework here seems to be based on (a) a rather uncritical reliance on the idea of the Kelsenian monist override; ${ }^{23}$ and (b) typical lawyerly preoccupation with the 'foregrounding of the form' and the resulting confusion of 'structures with outcomes' (cf. K ennedy 2004, Chapter 1). A gain, Kennedy's hypothesis seems to be vindicated rather consistently: while from the point of view of advancing the substantive agenda inscribed in the respective part of the

\footnotetext{
22 Interestingly, as every experienced local lawyer would know, the practical reality of the legalinstitutional dynamics in Central A sia is almost exclusively determined at the level of podzakonnye akty (decrees and edicts by the executive branch and various administrative agencies) and the role of the judiciary even in criminal trials has never been particularly significant.

${ }^{23}$ While the monist tradition has had many champions in international legal theory, none has left as prominent an impact on the discipline's imaginary as K elsen. On K elsen and monism in international law, see generally M alanczuk 1997, pp. 63-4.
} 
reforms package the pattern whereby the formal act of treaty ratification is treated as a de facto stand-in for the actual reforms themselves might seem extremely dysfunctional, ${ }^{24}$ from the point of view of achieving the dissemination of a certain mode of legal consciousness it is a perfectly effective solution. ${ }^{25}$

5. Principal tropes of the 'resistance discourse' as articulated after the 'aborted journey' moment

The tropes are listed in no particular order, but the list, in a way, almost speaks for itself:

(i) sovereignty and equality of cooperation tropes:

a. non-interference in the domestic affairs;

b. need for further dialogue;

c. strong doctrine of state immunity;

d. parity in the conduct of international relations;

${ }^{24}$ Cf. Sievers 2003a, p. 162: 'European donors, like OSCE, actively push the A arhus Convention because its appearance coincided with their general realization that [their] democracy and rule of law [projects] are on the decline in Central Asia. The Aarhus Convention operates now, as a result of this realization of development failure, often as more of a synecdoche for the need for Westernization than as a vehicle for sustainable development.'

${ }^{25} \mathrm{~A}$ revealing pattern can be observed in this regard in the regular admonitions by various international human rights NGOs directed to regional governments. In the light of K ennedy's argument about the langue, it is difficult, for example, not to see the grim irony in the following lamentation: 'At the UN and in bilateral negotiations, [this Central Asian] government has used habeas corpus and other so-called reforms as public relations tools, often to deflect criticism and as a substitute for substantive responses to specific queries and concerns.' (Human Rights Watch 2013, p. 2) Unsurprisingly, the solutions and recommendations section that follows it reads in large part as a litany of legislative initiatives: 'ratify the optional protocol to the convention against torture', 'amend the criminal procedure code', 'implement recommendations of international bodies', etc. (I bid., pp. 14-5.) 
e. developing country exceptionalism;

f. rejection of activist multilateral institutions as a projection of superpower hegemonism;

g. extreme formalism and absolute insistence on the rule of (international) law;

h. absolute right of self-determination.

(ii) cultural diversity tropes:

a. 'traditional society' exceptionalism;

b. international law as the mediation of differences in civilisational perspectives;

c. 'unique national heritage' exceptionalism;

d. (self-)Orientalism ${ }^{26}$ ('the East is a delicate affair');

e. historical stageism.

VI.

But where does Poulantzas's essay fit in all of this? What is its contribution to this story? In a nutshell, the answer seems to me to be twofold. First, it illuminates the underlying logic of that organicist dynamic which 'feeds' and 'anchors' the diffusion of the CLC as a world-historic process. Despite its obvious theoretical centrality to K ennedy's concept of legal consciousness, the organicist part remains by and large absent from his discussions of the operative mechanics of legal globalisation. Not so with Poulantzas. In the second place, it also uncovers the essentially imperialistic character of the diffusionary process, which in turn helps develop a greater insight into the general role of the CLC in the production of the broader regime of global governance - but also exploitation.

\footnotetext{
${ }^{26}$ I borrow the concept of 'self-Orientalism' here from Scott N ewton.
} 
Like K ennedy, Poulantzas, who is writing in the early 1970s, in the aftermath of the first Oil Crisis, is interested, to a large extent, in explaining the historical conditions of those processes which to the less attentive eyes come across as 'A mericanisation'. His principal goal, however, is not so much to describe the internal genealogy of these processes with a view to demonstrating, as Kennedy aims to do, that as these processes began to take off their content increasingly 'lost its distinctive Unitedstatesean quality' (Kennedy 2006a, p. 70). Quite on the contrary, Poulatnzas seeks expressly to reinsert the idea of a distinctive US national signature into the debate about international governance modalities that increasingly seeks to portray them as always-already (and rather unproblematically) globalised in content and character.

The argument has four parts:

(i) In its extended reproduction, late-stage capitalism is characterised 'by a double tendency: its reproduction within a social formation where it "takes root" and establishes its dominance, and its extension to the exterior of this formation, the two aspects ... acting at the same time' (Poulantzas 2008, p. 223). The expansionist process proceeds, in part, by the creation of unevenly balanced governance chains, in which some social formations come to assume the role of the dominant centre while others are assigned the role of the dominated and dependent periphery. This relationship of dominance and dependence has several dimensions and thus constantly brings into play not only direct but also indirect modalities of imperial governance. The common feature that is shared by all modalities is the removal of autonomy in the determination of institutional structural conditions within the dependent social formations:

A social formation is dominated and dependent when the articulation of its own economic, political, and ideological structure expresses constitutive and asymmetric relations with one or more social formations in a position of power in relation to that social formation. The organization of class relations and state apparatuses in the dominated and dependent formation reproduces within itself the structure of the relation 
of domination [which] corresponds to both indirect (through the position of the dominated formation in the imperialist chain) and direct (through direct investments) forms of exploitation of the popular masses of the dominated formations by the classes in power in the dominant formations. (Poulantzas 2008, p. 224)

Note the way in which Poulantzas conceptualizes the indirect modality of exploitation: the very insertion in the global imperial chain in the role of the 'recipient' formation, i.e. as a formation whose internal class structure and the configuration of state apparatuses reflect in their articulation the specific constitutive features of another, external social formation, is enough to bring into existence a relation of imperial domination. This echoes, of course, Marx's famous point in the Critique of the Gotha Programme: it is not the actual physical misery they suffer in their toil but their systematic separation from the product of their labour which turns workers into an exploited class; even when the level of absolute wages increases, the relationship of exploitation is not thereby abolished. ${ }^{27}$ Thus, even when the intensity of direct imperial governance over the given social formation never rises above the minimum threshold, the imperial character of the relationship is not dissipated.

(ii) Projecting Poulantzas's argument about social formations into the present context, one can extend this account to the geo-juridical dynamics of interaction between distinct legal systems. Starting from this angle gives us at once a much better conceptual handle with which to grasp the internal structure of the geo-juridical global space than Kennedy's world-systems-theory-inspired 'locales of production' and 'locales of reception'; ${ }^{28}$ and an explanation why, despite the fact that there appears to be little direct

\footnotetext{
27 ' [T] he system of wage labour is a system of slavery, and indeed of a slavery which becomes more severe in proportion as the social productive forces of labour develop, whether the worker receives better or worse payment' (M arx 1875, Part II).

${ }^{28}$ See Kennedy 2006a, p. 23: '[In] the process of geographic diffusion of [legal consciousness,] we can identify locales of "production" of a new transnational mode, contrasting locales where what happens is
} 
oppression of the European legal space by the US legal tradition, it still makes sense to describe that relationship as one of dominance and subordination.

M ore specifically, it allows us, firstly, to uncover with greater clarity the general organicist logic behind the diffusion of the CLC and also the particular mechanics by which this process reaches those domains in which it takes place:

The mode of production of the metropoles is reproduced in a specific form in the very interior of the dominated and dependent formations. [T] ]his induced reproduction of the [capitalist mode adopted within the metropoles] within these formations extends in a decisive manner to the sphere of their state apparatuses and their ideological forms. (Poulantzas 2008, p. 226)

Secondly, by analogising the concept of the mode of production to the mode of legal consciousness, it allows us to explain also the exact meaning of the broader structure of the geo-juridical global space as it exists today:

At the very time when the line of demarcation and cleavage between metropoles and dominated formations is becoming accentuated and is getting deeper, we are witnessing the establishment of a new line of demarcation in the metropoles' camp between the USA on the one hand and the other metropoles of imperialism, in particular Europe, on the other. [T] his hegemony of the USA is neither analogous to the hegemony of one metropolis over the others in the preceding phases nor does it differ from it only from a purely quantitative point of view; it appears in the establishment of relations of production characterizing A merican monopoly capitalism [AR: read 'identity/rights complex'] and its domination in the very interior of the other metropoles, and in the reproduction within the other metropoles of this new relation of dependence [and with that] of the political and ideological conditions of the development of the A merican imperialism. (Poulantzas 2008, p. 227)

This pattern of dependence, however, is not identical to the one that characterises the relationship between the metropoles and the global peripheries 'precisely to the extent reception with only minimal dialectical counterinfluence on the transnational mode, and cases in between. German legal thought was in this sense hegemonic between 1850 and 1900, French legal thought between 1900 and some time in the 1930s, and Unitedstatesean legal thought after 1950.' 
that these mteropoles continue to constitute real centres of capital accumulation [AR: read 'production of elements of the $\left[L^{\prime}\right.$ '] and to dominate the peripheral formations' (Poulantzas 2008, p. 227).

(iii) The most obvious expression of the rising 'dominance of A merican capital' for Poulantzas comes from three inter-linked patterns: the increase in the volume of the US capital investments abroad, including in Europe, especially in areas traditionally most given to capital concentration and centralisation dynamics (Poulantzas 2008, pp. 228-9); the growing predominance of the Foreign Direct Investment model over 'investment in securities' (Poulantzas 2008, p. 229); the increasing penetration of the organisational models and patterns of the division of labour characteristic of the US business experience into the 'interior' even of those multinational firms whose capital bases seem to come simultaneously from several different states (Poulantzas 2008, pp. 238-40).

What is the value of this particular set of observations? Quite considerable: adopting the same kind of analogist assumption as before gives us a much better grasp of the third main mechanism in Kennedy's story of how the CLC was diffused. It is not just the 'development of the US-style large international law firms' and non-profit public interest NGOs that we should focus our attention on as we proceed to trace the course of this diffusionary process. It is the spread of the distinctly US A merican (as opposed to, say, German or English) model for the organisation of the market of legal services and public interest lawyership on the whole; the establishment of direct presence by US firms and NGOs in foreign legal systems as well as the subsumption of local partner firms and NGOs in US-dominated alliances; the transfer of previously US-based top level partners into new foreign subsidiaries as well as the promotion of local staff to partnership on the strength of their previous experience in the US legal system (e.g. through graduate level education). 
(iv) Last but not least, the broader account of the operative mechanics of legal globalisation sketched out by Kennedy can also benefit, to my mind, quite significantly from Poulantzas's analysis of the general distinction in the context of the class structure of the dominated social formations between the 'national bourgeoisie' and the 'comprador bourgeoisie' elements. B riefly, this distinction unfolds as follows:

by national bourgeoisie is understood the autochthonous fraction of the bourgeoisie that ... occupies a relatively autonomous position in the ideological and political structure [vis-à-vis the foreign imperialist capital, which] has effects on [its class position inasmuch as it makes it] susceptible to the adoption of class positions which include it in the people and [thus] prone to a certain type of alliance with the popular masses. On the other hand, by comprador bourgeoisie is traditionally understood the bourgeois fraction that does not have its own base of capital accumulation, that operates in some sort as a simple 'intermediary' of foreign imperialist capital ..., and that from the simultaneously economic, political and ideological point of view is entirely held in fee by foreign capital. (Poulantzas 2008, p. 243)

With a certain reformulation (e.g, by substituting 'base of capital accumulation' for 'source of social and discursive capital'), I believe, this distinction can be adapted to describe a similar cleavage in the configuration of the 'national legal elites' and, perhaps, other similarly placed technocratic communities.

The relevance of such an operation should not be too difficult to deduce. A fter all, one of Kennedy's main motivations in developing his account in the first place was the aspiration to provide some sort of roadmap for how the 'progressive elites of the periphery' may resist against mechanically 'accept[ing] the prescription of the center that they simply "open" their economies and "reform" their legal systems, and accept the consequences for good or ill' (Kennedy 2006a, p. 24). Or, to look at it from a slightly different angle, one of the main questions that the story of the post-independence legalglobalisational encounter in Central Asia, retold in these pages, leaves to Kennedy's theory is precisely the question of what sort of conditions need to be present in the 
constitution of the social base of those national elites of the periphery, for the resistance project of the kind he describes to become successful.

\section{Acknowledgements}

The writing of this essay has benefited from conversations and exchanges with A rnulf B ecker Lorca, M ichelle B urgis-K asthala, Justin Desautels-Stein, Duncan K ennedy, Scott Newton, Djakhongir Saidov, and Eric Sievers. All mistakes and omissions are mine and mine alone.

\section{R eferences}

Alekseev, S.S. 1973. Problemy teorii prava v 2 tomakh. Sverdlovsk: Sverldovskiy yuridicheskiy institute.

Althusser, Louis. 1969. (B en B rewster, trans.) F or M arx. London, V erso.

A n-Naim, A bdullahi. 2000. Human rights and Islamic identity in France and U zbekistan: M ediation of the local and global. Human Rights Q uarterly 22(4): 906-941.

Bakker, Edwin. 2006. Repression, political violence and terrorism: The case of Uzbekistan. Helsinki M onitor 17(2): 108-118.

Berman, Nathaniel. 1997. A ftershocks: Exoticization, normalization, and the hermeneutic compulsion. U tah Law Review 1997(2):281-286.

Blackmon, Pamela (ed.). 2011. In the shadow of Russia: Reform in Kazakhstan and U zbekistan. East Lansing: M U Press.

Booker, Chistopher. 2004. The seven basic plots. London: Continuum.

Bourdieu, Pierre. 1990. The logic of practice. (Richard Nice, trans.) London: Polity.

Brill Olcott, Martha. 2005. Central Asia's second chance. Washington: Carnegie Endowment. 
Cooley, A lexander. 2012. Great games, local rules. N ew Y ork: Oxford University Press.

Cummings, Sally. 2005. Kazakhstan: Power and the elite. London: IB Taurus.

Cummings, Sally and Michael Ochs. 2002. Turkmenistan: Saparmurat Niyazov's inglorious isolation. In Power and change in Central Asia, ed. S. Cummings, 115129. London: Routledge.

Dave, Bhavna. 2007. Kazakhstan - Ethnicity, language and power. London: Routledge.

Dezalay, Yves and Bryant Garth. 2002. The internationalization of palace wars: Lawyers, economists, and the contest to transform Latin American states. Chicago: University of Chicago Press.

Foust, Joashua. 2012. The economist's Kyrgyz condescension. At http://registan.net/2012/09/05/the-economists-kyrgyz-condescension/.

Gleason, Gregory. 2003. M arkets and politics in Central Asia. N ew Y ork: Routledge.

Horwitz, Morton. 1992. The transformation of American law: 1870-1960. New Y ork: Oxford U niversity Press.

Human Rights Watch, 2004. Political freedoms in Kazakhstan. At http://www.hrw.org/reports/2004/04/05/political-freedoms-kazakhstan.

Human Rights Watch, 2008. An atmosphere of quiet repression'. At http://www.hrw.org/reports/2008/12/01/atmosphere-quiet-repression.

Human Rights Watch, 2013. Submission to the UN Committee against torture. At http://www.hrw.org/news/2013/10/28/human-rights-watch-submission-unitednations-committee-against-torture-uzbekistan.

International Crisis Group, 2009. Tajikistan: On the road to failure. At http://www.crisisgroup.org/ /media/Files/asia/centralasia/tajikistan/162_tajikistan_on the road_to failure.pdf. 
International Crisis Group, 2013. Kazakhstan: Waiting for change. At http://www .crisisgroup.org/ /media/Files/asia/central-asia/kazakhstan/250kazakhstan-waiting-for-change.pdf.

Ishiyama, John. 2002. Neopatrimonialism and the prospects for democratization in the Central A sia Republics. In Power and change in Central Asia, ed. S. Cummings, 42-58. London: Routledge.

Johnson, Rob. 2007. Oil, Islam and conflict: Central Asia since 1945. Chicago: The University of Chicago Press.

J ones Luong, Pauline. 2002. Institutional change and political continuity in Post-Soviet Central Asia. Cambridge: Cambridge University Press.

Kennedy, David. 2004. The dark sides of virtue: Reassessing international Humanitarianism. Princeton: Princeton U niversity Press.

Kennedy, Duncan. 2001. A semiotics of critique. Cardozo Law Review 22(3-4):11471189

Kennedy, Duncan. 2003. Two globalizations of law \& legal thought: 1850-1968. Suffolk University Law Review 36(3): 631-679.

Kennedy, Duncan. 2006a. Three globalizations of law and legal thought: 1850-2000. In The new law and economic development: A critical appraisal, ed. D.M. Trubek and A. Santos, 19-73. Cambridge: Cambridge U niversity Press.

Kennedy, Duncan. 2006b. The rise and fall of classical legal thought. W ashington: B eard Books.

Kennedy, Duncan. 2008. Legal reasoning: Collected essays. Aurora, Co.: The Davies Group Publishers. 
Kennedy, Duncan. 2011. A transnational genealogy of proportionality in private law. In The foundations of European private law, ed. R. Brownsword et al., 185-220. Oxford: Hart.

Lukacs, Georg. 1971. History and class consciousness. (Rodney Livingstone, trans.) London: Merlin.

Malanczuk, Peter (ed.). 1997. Akehurst's modern introduction to international law. $7^{\text {th }}$ edition. London: Routledge.

Mal'ko, A.V . 1996. Ekzamen po teorii gosudarstva i prava. M oskva: Gardarika.

Marx, Karl. 1875 [1970]. Critique of the Gotha programme. Moscow: Progress Publishers. http://www.marxists.org/archive/marx/works/1875/gotha/index.htm.

Menon, Rajan and Hendrik Spruyt. 1999. The limits of neorealism: Understanding security in Central A sia. Review of International Studies 25(1): 87-105.

Parakhonsky, Boris. 2000. Central A sia: Geostrategic survey. At http://www.cac.org/dataeng/parakhonsk.shtml.

Poulantzas, Nicos. 2008. Internationalization of capitalist relations and the nation-state. In The Poulantzas reader: Marxism, law, and the state, ed. J. Martin, 220-257 (Elizabeth Hindess, trans.). London: V erso.

Said, Edward. 1978. Orientalism. London: Routledge.

Sievers, Eric. 2003a. The post-Soviet decline of Central Asia: Sustainable development and comprehensive capital. London: Routledge.

Sievers, Eric. 2003b. Modern regression: Central A sian markets, democracy, and spoils system. Harvard Asia Quarterly 7(1):43-52.

Slaughter, A nne-M arie. 2003. Global government networks, global information agencies, and disaggregated democracy. Michigan Journal of International Law 24(4):1041-1075. 
Smith, Myles. 2013. Central Asia in 2013: What not to look for. At http://registan.net/2013/01/19/central-asia-in-2013-what-not-to-look-for/.

Uspensky, B.A. and Y.M. Lotman. 1978. On the semiotic mechanism of culture. New Literary History 9(2): 211-232.

White, Hayden. 1978. Tropics of discourse. Baltimore: The Johns Hopkins University Press.

W ooden, A manda and Christoph Stefes (eds). 2009. The politics of transition in Central Asia and Caucasus. London: Routledge. 